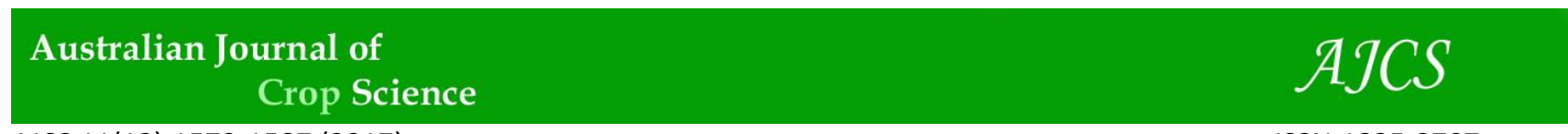

AJCS 11(12):1579-1587 (2017)

ISSN:1835-2707

doi: 10.21475/ajcs.17.11.12.pne741

\title{
Biochemical response of Tachi-branco (Tachigali vulgaris L.G. Silva \& H.C. Lima) in function of sources and doses of nitrogen
}

Pedro Henrique Oliveira Simões ${ }^{1}$, Kerolém Prícila Sousa Cardoso ${ }^{1}$, Vitor Resende do Nascimento ${ }^{1}$, Juscelino Gonçalves Palheta ${ }^{1}$, Manoel Tavares de Paula ${ }^{2}$, Nelivelton Gomes dos Santos ${ }^{2}$, Jéssica Taynara da Silva Martins ${ }^{3}$, Liliane Corrêa Machado ${ }^{3}$, Karollyne Renata Souza Silva ${ }^{3}$, Denmora Gomes de Araújo $^{4}$, Cândido Ferreira de Oliveira Neto ${ }^{4}$, Ana Ecídia de Araújo Brito ${ }^{*}$

${ }^{1}$ Department of Forest Sciences, Federal Rural University of Amazonia, Belém-Pará-Brazil

${ }^{2}$ Center for Natural Sciences and Technology, University of the State of Pará, Belém-Pará-Brazil

${ }^{3}$ Agronomist student at Universidade Federal Rural da Amazônia- UFRA, Belém, Pará, Brazil

${ }^{4}$ Institute of Agronomists Sciences, Universidade Federal Rural da Amazônia, Belém, Pará, Brazil

*Corresponding author: ecidiabrito@hotmail.com

\begin{abstract}
This study aimed to evaluate the effects of application of nitrogen sources and doses in the biochemical response of seedlings of Tachigali vulgaris L. G. Silva \& H. C. Lima. The seedlings were grown in pots containing $3 \mathrm{dm}^{3}$ of soil. Nitrogen sources such as urea $\left[\left(\mathrm{NH}_{2}\right)_{2} \mathrm{CO}\right]$, ammonium nitrate $\left(\mathrm{NH}_{4} \mathrm{NO}_{3}\right)$, ammonium sulfate $\left[\left(\mathrm{NH}_{4}\right)_{2} \mathrm{SO}_{4}\right]$ and calcium nitrate $\left[\mathrm{Ca}\left(\mathrm{NO}_{3}\right)_{2}\right]$ were tested in five doses of $0,75,150,225$ and $300 \mathrm{mg} \mathrm{dm}^{-3}$. They were applied as a solution in four portions, 25, 50, 75 and 100 days after transplanting. The experimental unit consisted of a vase and a randomized block design (RBD) in factorial scheme $(4 \times 5)$, corresponding to 4 sources and 5 doses, with four replications, totally 80 vessels. The biochemical analyzes were performed at the end of the experiment and nitrate levels, nitrate reductase enzyme activity, free ammonium, total soluble amino acids, total soluble proteins, carbohydrates, sucrose and chlorophylls were determined. There was a reduction in the concentration of protein in leaf and root, with the application of ammonium nitrate and calcium nitrate. The conversion of nitrate into the root in amino acids shown to be dependent to the oxidation of carbohydrates, causing the reduction of the concentration of this solute increases with the supply $\mathrm{NO}_{3}{ }^{-}$. The results showed that for production of Tachigali vulgaris seedlings the dose of $150 \mathrm{mg} \mathrm{dm}^{-3}$ of N, applied in a piecemeal manner, at 25, 50,75 and 100 days of transplanting with the ammonium nitrate fertilizer can be recommended.
\end{abstract}

Keywords: Forest species, Organic solutes, Photosynthetic pigments. Abbreviations: ERO_Reactive oxygen species, DM_dry matter.

\section{Introduction}

The Tachi-branco (Tachigali vulgaris L. G. Silva \& H. C. Lima, Leguminosae Caesalpinioideae) is a species that gathers promising characteristics for energy plantations in the Brazilian Amazon and bordering regions (Carpanezzi et al., 1983). Although the available information is scarce, its wood is considered to be good characteristics for firewood and charcoal (Ducke, 1949), since it has characteristics similar to eucalyptus wood, such as the yield of weight and volume in the carbonization process and higher calorific value of charcoal (Vale et al., 2002). In addition to this, there are high values of annual increase, reaching $2.5 \mathrm{~m}$ year and $3.4 \mathrm{~cm}$ year in height and diameter, respectively, in full sun (Yared, 1990). It is estimated a rotation of 5 to 10 years for plantations with energetic purposes. The production of forest seedlings in quality and quantity is one of the most important phases for the establishment of forest stands with native species. It is conditioned by the use of quality seeds, appropriate cultivation substrates and adequate fertilization, (Scheer et al., 2010). The commercial substrates do not always provide satisfactory amounts of nutrients, and when enriched with fertilizers their efficiency is increased. Associated with the type of container and substrate, the application of nutrients, especially macronutrients in the growth of the seedlings, has aroused the interest of several forest researchers. Several works have been conducted to understand the best form of fertilization in forest species for correct recommendation. The use of chemical fertilizers is; therefore, a usual practice in forest nurseries, functioning as a valuable tool in controlling the size and vigor of seedlings (Ribeiro et al., 2001). As a key component of many macromolecules, including proteins and nucleic acids, nitrogen is essential for normal plant growth and development (Sinfield et al., 2010). In plant metabolism, it participates as a constituent of proteins, coenzymes, nucleic acids, cytochrome, chlorophyll, pigments and by-products (Silva et al., 2011). When there is a deficiency of this nutrient in the growth substrate, it is translocated from the older leaves to the younger parts of the plant. In addition, it affects leaf initiation and expansion rates, leaf size and leaf senescence intensity (Schroder et al., 2000). Despite the importance of this nutrient (Davies, 2000), there are few studies on plants involving this chemical element. The nitrogen $(\mathrm{N})$ in ammoniacal or nitric form influences several physiological and biochemical processes in plants, such as photosynthesis and enzymatic activities of $\mathrm{N}$ metabolism (Borgognone et al., 2013). Development and morphology 
(Zhu et al., 2000) depend on species and plant variety (Lasa et al., 2002). In many production systems, nitrogen availability is almost always a limiting factor, influencing plant growth more than any other nutrient (Bredemeier and Mundstock, 2000). Thus, it has been sought to reduce soil nitrogen losses, given its importance and high mobility to improve the absorption and metabolization of $\mathrm{N}$ within the plant, maximizing the efficiency of its use. The current scientific research is focused on the economic use of fertilizers, being of the utmost importance to the evaluation of factors that interfere in the processes of the nitrogen cycle as well as the factors associated to the technology of use of the nitrogen sources, to minimize the losses of the soil-plant (Cantarella, 2007). There is a permanent need for actions that lead to a substantial increase in the efficient use of nitrogen. However, it mainly depends on actions that allow greater technological advances for greater efficiency of nitrogen fertilizations. This is fundamental when it is sought to increase productivity with sustainability (Lopes et al., 2007). The present work aimed to evaluate the effects of the application of different sources and nitrogen rates on the biochemical response of Tachigali vulgaris L. G. Silva \& $H$. C. Lima.

\section{Results}

\section{Nitrate concentration}

The nitrate concentration showed a quadratic adjustment in response to levels of nitrogen sources, ammonium nitrate and calcium nitrate in leaf and ammonium sulfate and ammonium nitrate in the root (Fig.1). In leaf, The nitrate concentration showed similar behavior to $\mathrm{N}$ supply, more ammonium nitrate and nitrate, ranging from only $12.4 \%$ in the mean calcium nitrate $\left(0.13 \mathrm{mmol} \mathrm{NO}_{3}{ }^{-} / \mathrm{kg} \mathrm{DM}\right)$ and ammoniumm ( $0.11 \mathrm{mmol}$ of $\left.\mathrm{NO}_{3}{ }^{-} / \mathrm{kg} \mathrm{DM}\right)$, demonstrating the presence of $\mathrm{NH}_{4}{ }^{+}$. In the present study, it did not affect the accumulation of nitrate in leaves. In root, quadratic adjustments were observed; however, with the concavity of the curve different, showing that the maximum nitrate concentration would be observed at higher nitrogen levels than those studied to ammonium nitrate and ammonium sulfate. The other sources were not significant for the adjustment of the regression model $(p>0.05)$.

\section{Activity of reductase of nitrate}

The activity of reductase of nitrate in leaf showed some variantion, considering the mean values, ranging from 0.34 to $0.17 \mu \mathrm{mol}$ de $\mathrm{NO}_{2}^{-} \mathrm{g}^{-1} \mathrm{~h}^{-1}$ with a incremente of dose 0 to 300 $\mathrm{mg} \mathrm{\textrm {dm } ^ { - 3 }}$ of nitrogen, or the maximum dose of $\mathrm{N}$ has a negative effect on the enzyme activity as shown in (Fig. 2). Through the regression equation we found that the maximum value for the activity of $\mathrm{RNO}_{3}{ }^{-}$in leaf is $1.31 \mu \mathrm{mol}$ of $\mathrm{NO}_{2}{ }^{-} \mathrm{g}^{-}$ ${ }^{1} \mathrm{~h}^{-1}$ by providing dose of $170 \mathrm{mg} \mathrm{dm}^{-3}$ of $\mathrm{N}$. From this dose, the increase in the supply of nitrogen promoted decrease of enzyme activity. The activity of nitrate reductase in the root (Fig. 2) showed a quadratic effect and increased with increasing $\mathrm{N}$ doses, using ammonium nitrate, confirming that the presence of $\mathrm{NO}_{3}{ }^{-}$soil favors the activity of the enzyme.

\section{Free ammonium}

It was possible to adjust the regression models for all tested nitrogen fertilizer sources, for the free ammonium variable in the roots (Fig. 3). As observed in leaf, ammonium nitrate also presented positive adjustment to the linear model. The urea, ammonium sulphate and calcium nitrate showed quadratic effect of ammonium accumulation depending on the doses of $\mathrm{N}$. The maximum dose accumulation found for the sources that showed quadratic effect such as $261.38(171.30 \mathrm{mmol}$ of $\left.\mathrm{NH}_{4}^{+} \mathrm{kg}^{-1} \mathrm{DM}\right), 242$ (98.41 mmol of $\left.\mathrm{NH}_{4}^{+} \mathrm{kg}^{-1} \mathrm{DM}\right)$ and $278.17 \mathrm{mg} \mathrm{dm}{ }^{-3}$ (70.12 mmol of $\mathrm{NH}_{4}^{+} \mathrm{kg}^{-1} \mathrm{DM}$ ) for urea, ammonium sulfate and calcium nitrate, respectively. However, the nitrate concentrations were also higher in the roots than in the leaves, which did not happen for T. vulgaris seedlings, where the maximum concentration of $\mathrm{NO}_{3}{ }^{-}$in leaf (0.201 mmol of $\left.\mathrm{NO}_{3}^{-} \mathrm{kg}^{-1} \mathrm{DM}\right)$ was bigger than the maximum concentration in root $\left(0.063 \mathrm{mmol} \mathrm{de} \mathrm{NO}_{3}^{-} \mathrm{kg}^{-1}\right.$ $\mathrm{DM})$. These results may indicate that the sheets are the preferred sites of reduction of $\mathrm{NO}_{3}^{-}$, because the reductase activity of the nitrate enzyme is relatively high, which explains the higher nitrate concentration of the leaves in relation to the concentration of the roots.

\section{Total soluble aminoacids}

In leaves, the ammonium sulfate and ammonium nitrate sources provided adjustment of the quadratic model as a function of $\mathrm{N}$ levels and calcium nitrate source set to the positive linear model. As for urea, there was no significance ( $p>0.05$ ) for adjusting the regression model (Fig. 4). For the accumulation of aminoacids in the root, urea, ammonium sulfate and ammonium nitrate were significant for the adjustment of the regression model, which is quadratic in the three sources.

\section{Total soluble proteins}

The data of protein accumulation in sheet for the significant interaction of the factors (F $\times$ D) $(p \leq 0.05)$, adjusted to the quadratic regression model according to the $\mathrm{N}$ levels, with a tendency to decrease due to the increase of the dose, only for ammonium nitrate and calcium nitrate (Fig. 5). In the case of protein content in the root, the main effect of doses showed significance for setting the regression equation to curve following the same trend observed for the sheet.

\section{Carbohydrates}

For the accumulation of carbohydrates in the leaf, there was a significant effect for the interaction between factors (F x D). Regarding the sources urea and ammonium nitrate, a quadratic effect with a tendency to decrease the accumulation of carbohydrates with increasing doses and negative linear effect on calcium nitrate was observed. It depends on the $\mathrm{N}$ rates as shown in (Fig. 6). The $\mathrm{N}$ rates of ammonium sulfate showed no significant response correspond to accumulation of carbohydrates in the sheet to fit the regression model $(p>0.05)$. The analysis of the total content of soluble carbohydrates in the roots (Fig. 6) showed decreased content due to the increase of $\mathrm{N}$ rates for the application of urea, similar to behavior observed in the leaves. There was negative linear effect for this source in the setting of the regression model. The other sources were not significant for the adjustment of the equation $(p>0.05)$. Comparing treatment without fertilizer and the one with the highest dose $\left(300 \mathrm{mg} \mathrm{dm}^{-3}\right)$, the contents of total carbohydrates decreased approximately 1.6 times, reaching $0.37 \mathrm{mmol}$ of GLU g ${ }^{-1}$ $\mathrm{DM}$, while the seedlings without nitrogen showed $0.60 \mathrm{mmol}$ de GLU g ${ }^{-1}$ DM. 

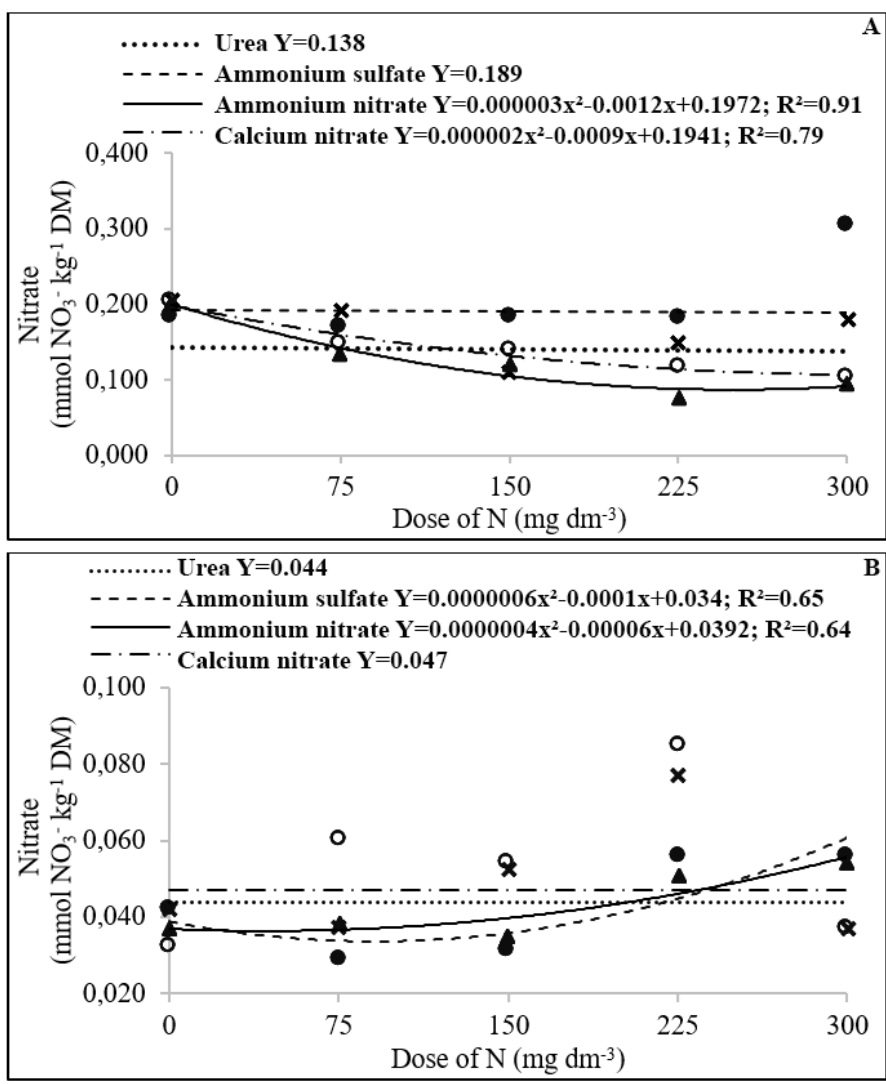

Fig 1. Concentration of nitrate accumulated in leaves (A) and roots (B) of T. vulgaris seedlings, respectively, according to the sources and nitrogen at the end of the experiment $(\mathrm{p} \leq 0.05)$.
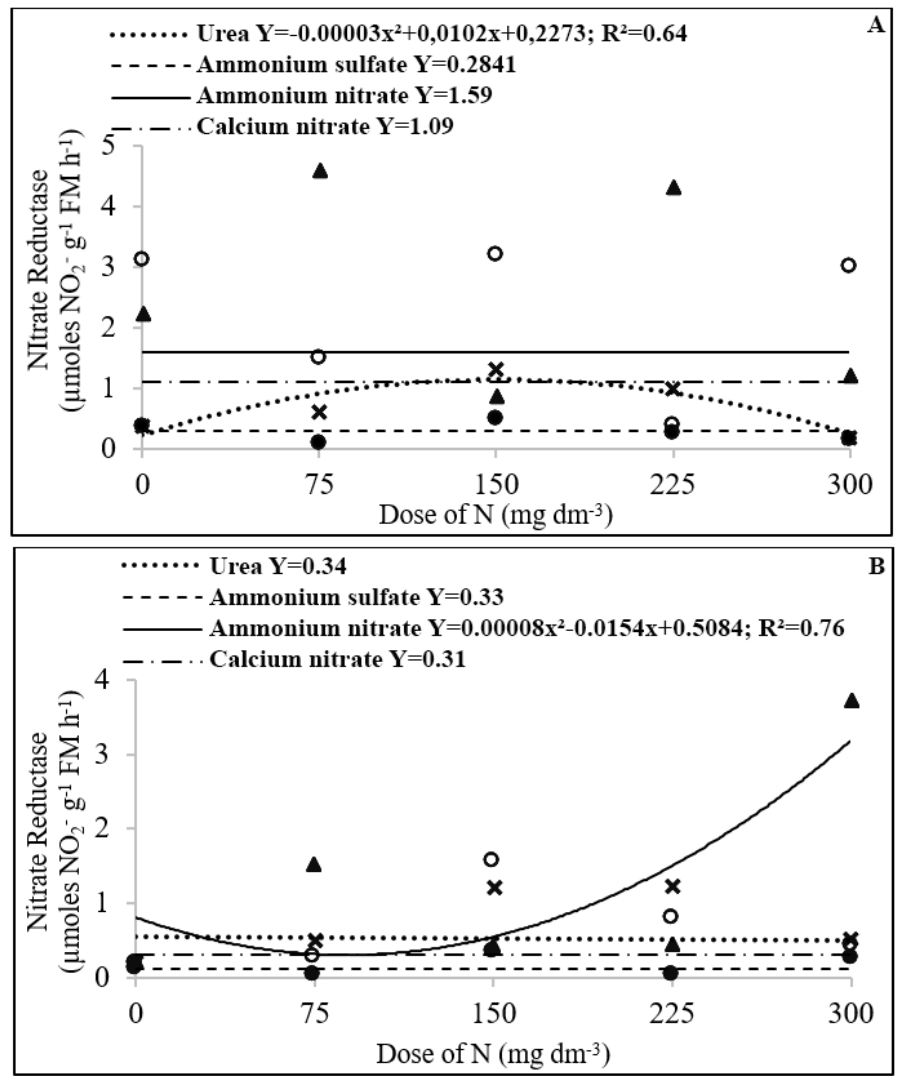

Fig 2. Nitrate reductase enzyme activity in leaves (A) and roots (B) of T. vulgaris seedlings (fresh matter - FM), respectively, according to the sources and nitrogen at the end of the experiment $(\mathrm{p} \leq 0.05)$. 

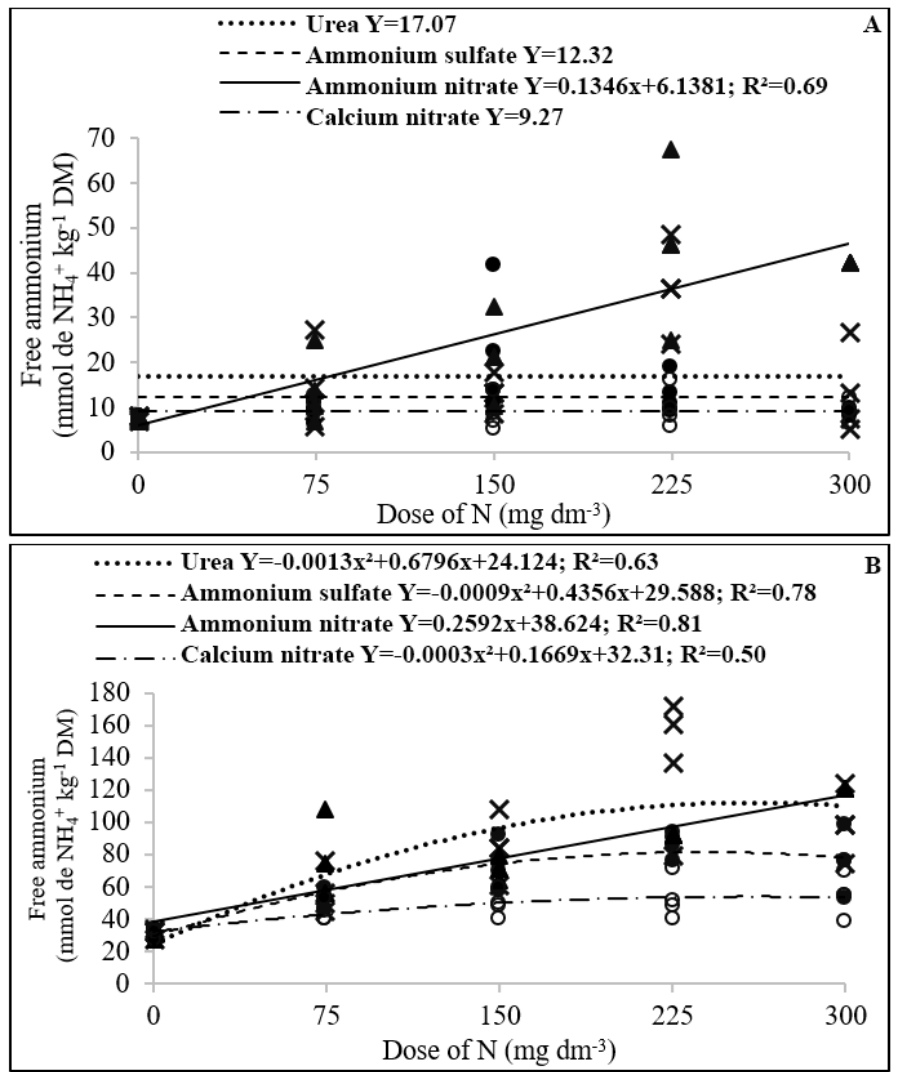

Fig 3. Accumulated free ammonium concentration in leavs (A) and roots (B) of T. vulgaris seedlings, respectively, according to the sources and doses of nitrogen at the end of the experiment $(\mathrm{p} \leq 0.05)$.
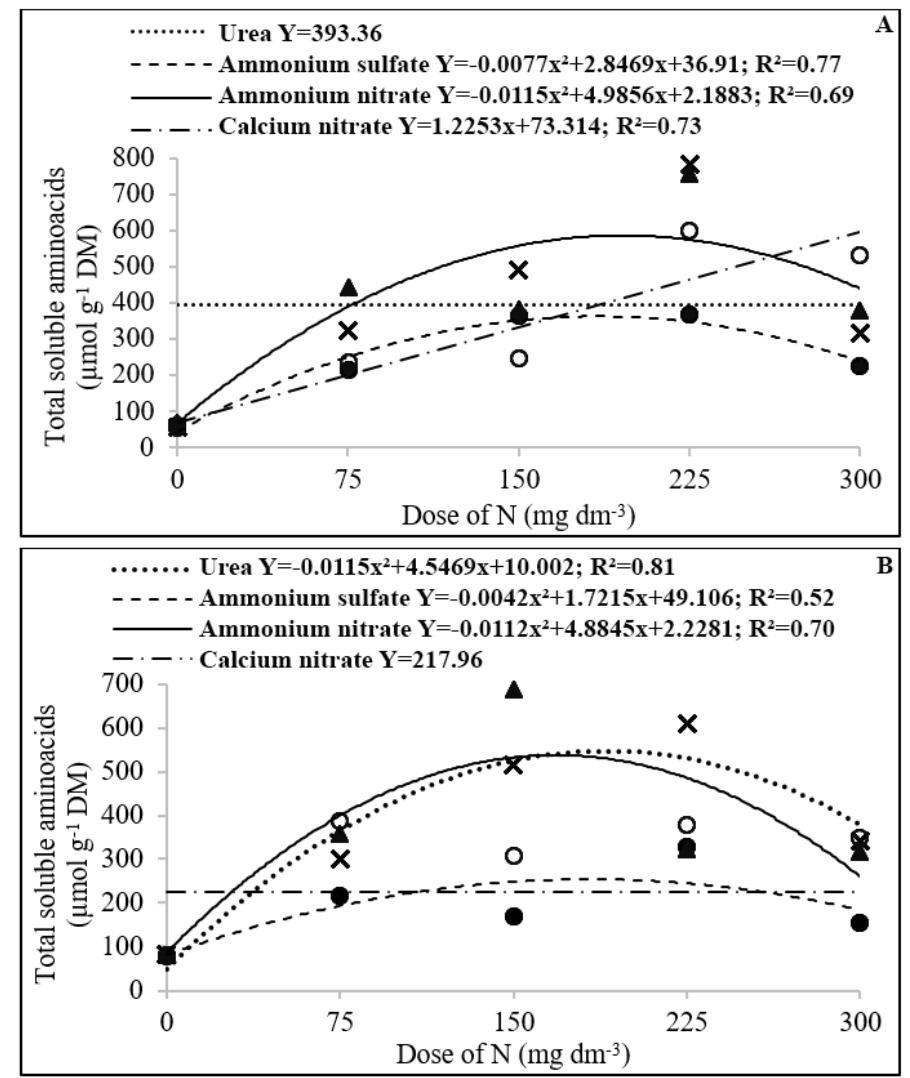

Fig 4. Total soluble aminoacids concentration in leaves (A) and roots (B) of T. vulgaris seedlings, respectively, according to the sources and doses of nitrogen at the end of the experiment $(\mathrm{p} \leq 0.05)$. 

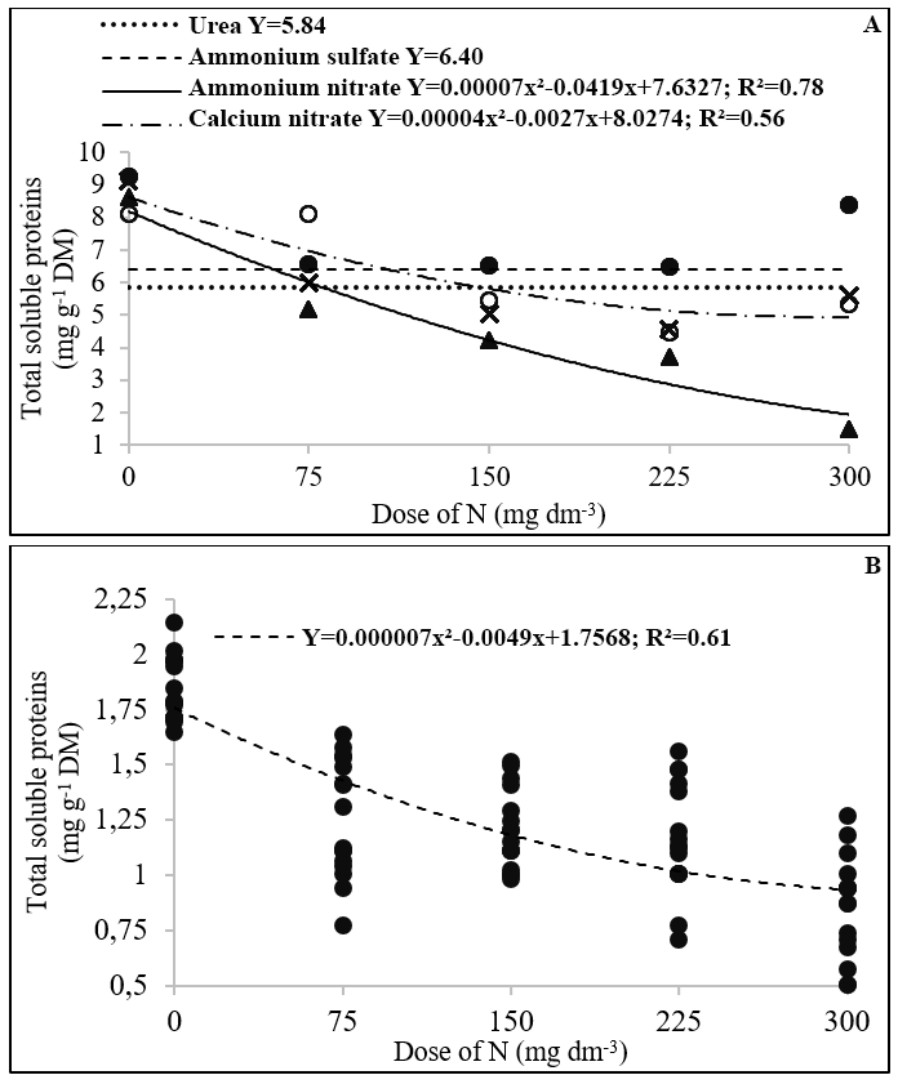

Fig 5. Concentration of soluble proteins in leavs (A) of T. vulgaris seedlings as a function of nitrogen sources and doses, and in roots (B) as a function of nitrogen doses, at the end of the experiment $(\mathrm{p} \leq 0.05)$.

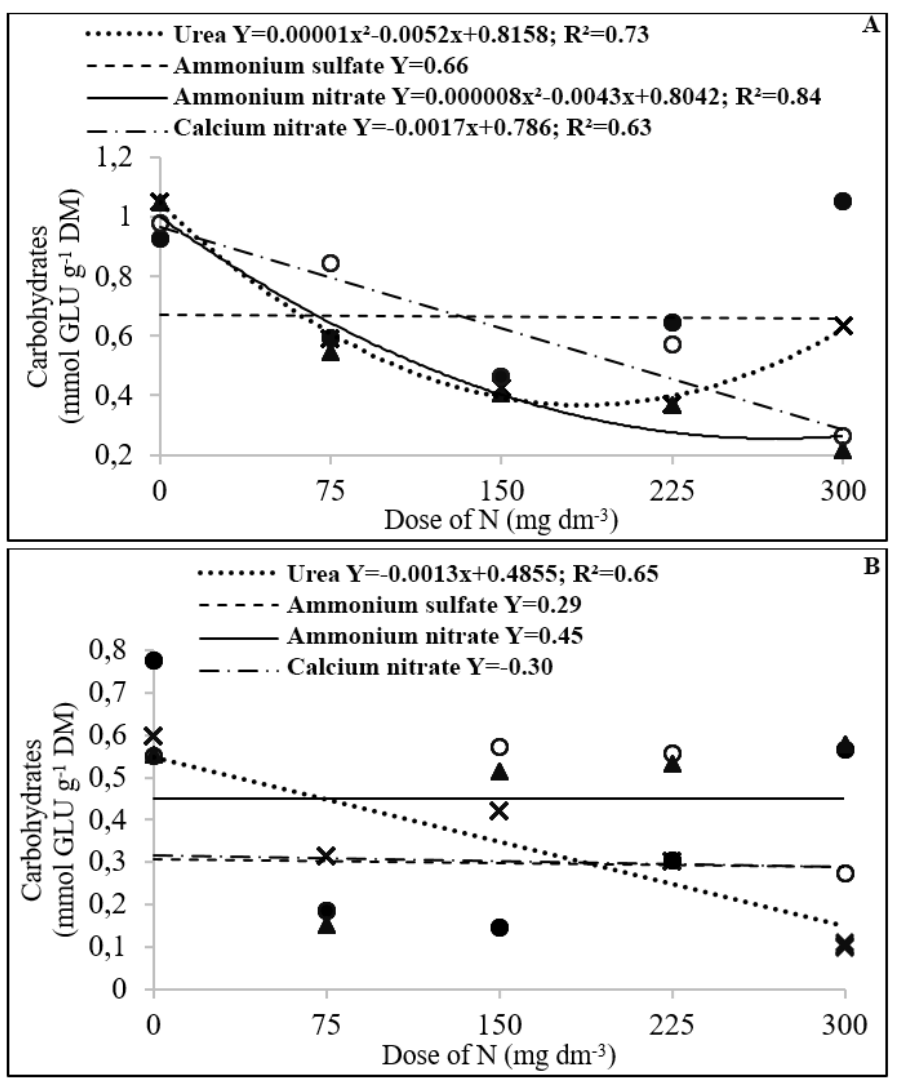

Fig 6. Concentration of carbohydrates in leavs (A) and roots (B) of T. vulgaris seedlings, respectively, according to the sources and doses of nitrogen at the end of the experiment $(\mathrm{p} \leq 0.05)$. 


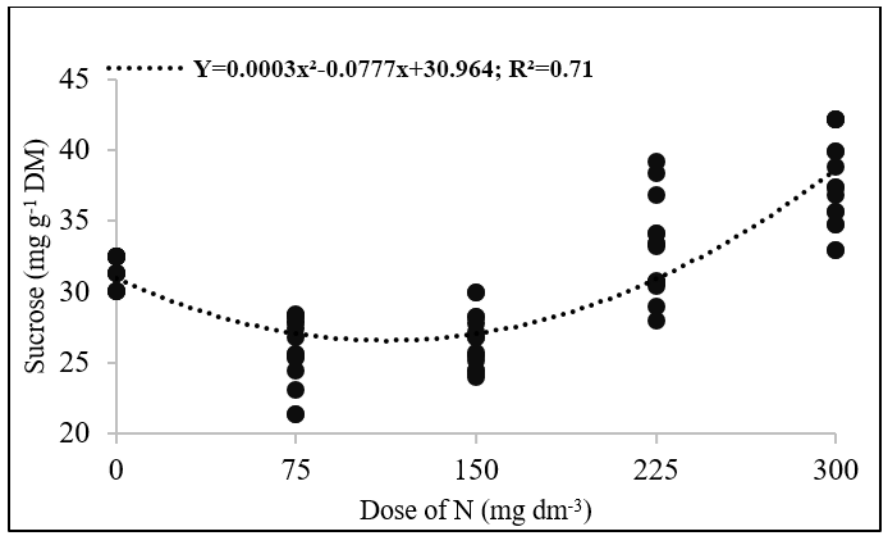

Fig 7. Concentration of sucrose in leaves of T. vulgaris seedlings as a function of nitrogen doses at the end of the experiment $(\mathrm{p} \leq 0.05)$.
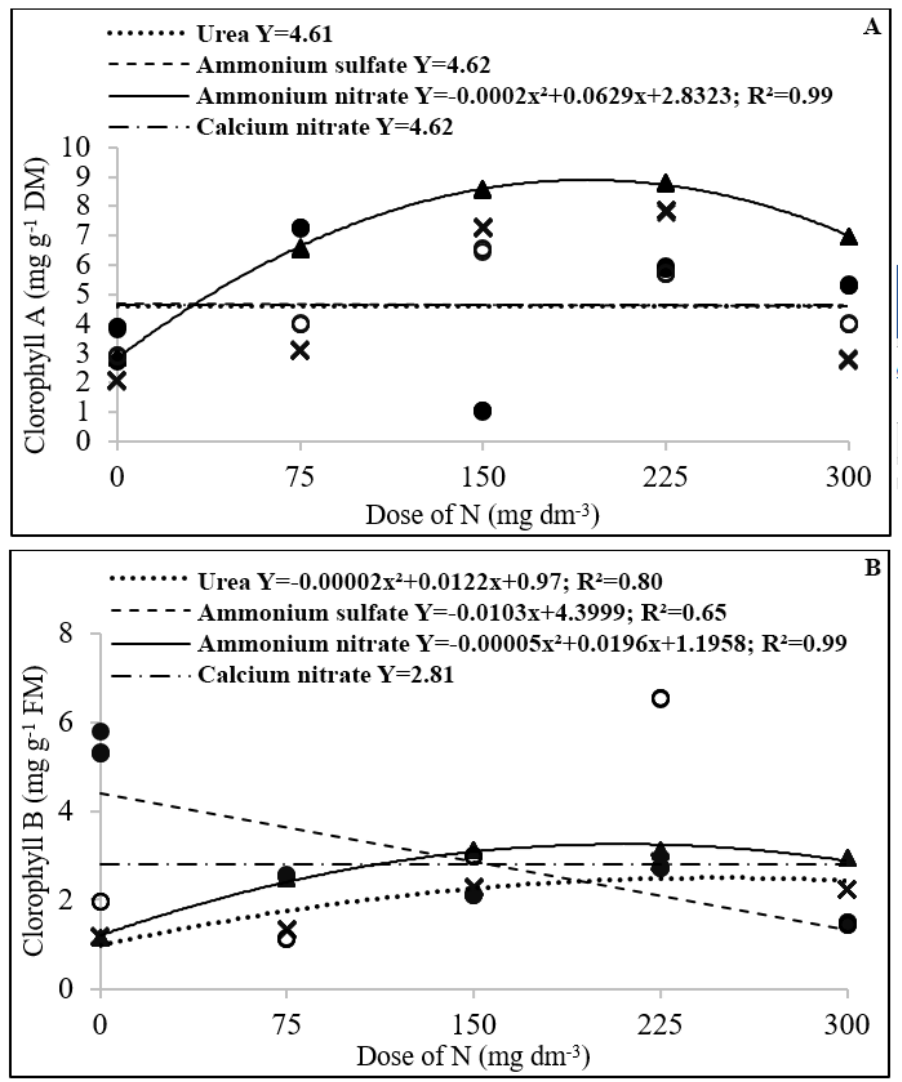

Fig 8. Chlorophyll content A (A) and B (B), respectively, in leaves (fresh matter - FM) of seedlings of T. vulgaris according to the sources and doses of nitrogen at the end of the experiment $(\mathrm{p} \leq 0.05)$.

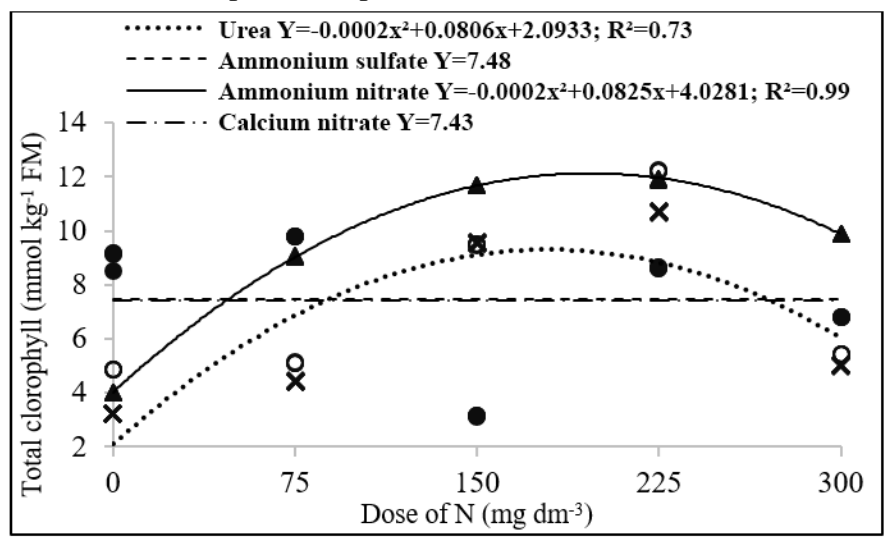

Fig 9. Content of total chlorophyll in leaves (fresh matter - FM) of seedlings of T. vulgaris according to the sources and doses of nitrogen at the end of the experiment $(\mathrm{p} \leq 0.05)$. 


\section{Sucrose}

For the sucrose content of leaves, the interaction between nitrogen sources and doses was not significant $(p>0.05)$. However, the main effect of $\mathrm{N}$ rates was verified on the accumulation of sucrose in the leaves (Fig. 7). The $\mathrm{N}$ provided the maximum accumulation of sucrose up to 300 $\mathrm{mg} \mathrm{dm} \mathrm{m}^{-3}$.

\section{Chlorophylls $A$ and $B$}

The $\mathrm{N}$ dose of $157.25 \mathrm{mg} \mathrm{dm}^{-3}$ by applying ammonium nitrate caused the highest values of Chla. Under thi treatment the Chla content reached to $7.78 \mathrm{mg} \mathrm{g}^{-1} \mathrm{DM}$, which is an increase of about $170 \%$ compared to the treatment without fertilization, which showed approximately $2.88 \mathrm{mg} \mathrm{g}^{-1} \mathrm{DM}$ of Chla in average. For chlorophyll content B (Chlb), there was a quadratic effect on the basis of urea and ammonium nitrate doses and negative linear effect for the doses of ammonium sulfate. The regression model for calcium nitrate showed no significance $(p>0.05)$. The application of ammonium sulfate indicates that the fertilizer in question adversely affected Chlb levels. Doses of maximum efficiency with urea ammonium nitrate sources and were of $227\left(2.83 \mathrm{mg} \mathrm{g}^{-1} \mathrm{DM}\right)$ and $196 \mathrm{mg} \mathrm{dm}^{-3}$ (3.13 $\left.\mathrm{mg} \mathrm{g}^{-1} \mathrm{DM}\right)$, respectively.

\section{Total chlorophyll}

The effect of $\mathrm{N}$ rates tested on the total chlorophyll content (Chlt) was set in the quadratic model for urea and ammonium nitrate, indicating that the species responded positively to the application of $\mathrm{N}$ for this variable. Similar behavior was found for contents of Chla and Chlb for most of the sources of N. The maximum efficiency doses found to Chlt were 201.5 (10.71 $\left.\mathrm{mg} \mathrm{g}^{-1} \mathrm{DM}\right)$ and $206.25 \mathrm{mg} \mathrm{dm}^{-3}$ (11.91 $\left.\mathrm{mg} \mathrm{g}^{-1} \mathrm{DM}\right)$, for urea and ammonium nitrate, respectively (Fig. 9). There was no significant effect on $\mathrm{N}$ doses of ammonium sulphate and calcium nitrate on this variable.

\section{Discusion}

The absence of fertilization or the addition of $\mathrm{N}$ at high doses has been considered limiting, causing changes in the metabolism of the plants during the evaluation period.

For the activity of nitrate reductase enzyme $\left(\mathrm{RNO}_{3}{ }^{-}\right)$, the interaction between nitrogen sources and doses was significant $(p \leq 0.05)$ (Table 3$)$. The leaf was responded to urea while root to ammonium nitrate. No significant interaction between factors $(F \times D)$ in the setting of the regression model was observed other sources in leaf and root $(p>0.05)$.

Application of nitrogen, with largest experimental doses (225 and $300 \mathrm{mg} \mathrm{dm}^{-3}$ ) of urea, may have caused increased excretion of $\mathrm{H}^{+}$ions by roots of $T$. vulgaris seedlings. Consequently, acidification of the soil $(\mathrm{pH})$ and decreased availability of molybdenum may have been occurred. This acidification observed for absorbing $\mathrm{NH}_{4}{ }^{+}$can affect the availability and the biological activity of various nutrients in the root zone (Vian and Kiehl, 2010). The concentration of ammonium in leaves showed a positive linear adjustment only for the ammonium nitrate, providing $\mathrm{NO}_{3}{ }^{-}$more than $\mathrm{NH}_{4}{ }^{+}$. Increasing $\mathrm{N}$ rates can elevate ammonium concentration in leaves (Fig 3). The other sources were not significant for the adjustment of the regression model $(p>0.05)$. However, it is observed that the application of urea increased this variable higher than the other sources, when the average ammonium accumulation for each source analyzed.

There are various symptoms caused by excess ammonia, which may occur in various plants. Some of them symptoms are reduced plant growth, short and stunted roots (Jampeetong et al., 2012), chlorosis, necrosis, stunting and wilting of leaves and brown color of root and stem, showing signs of senescence (Neuberg et al., 2010).

The increased concentration of free aminoacids occurs primarily as a result of the increase in the biosynthesis of these compounds (Oliveira et al., 2006). Furthermore, protein degradation allows the recycling of free amino acids, leading to increase concentration of these compounds (Beltrão et al., 2007). In this study, we also observed the increase in the total free amino acid content and reduced total soluble protein content. It is believed that the ROS cause damage to the photosystem by the fact that inhibits protein synthesis and consequently D1 synthesis, the major protein of PSII (Silva et al., 2011). It explains that the increase in protein content as a function of $\mathrm{N}$ can be directly related to the synthesis of structural and enzymatic proteins, which are responsible for synthesis of other proteins and metabolic intermediates that plant can store them for use upon their metabolic needs. However, for $T$. vulgaris species, decrease of the protein content indicates a similar behavior of plants under oxidative stress. It may be related to production of ROS and; therefore, damage to the photosystems denaturation and inhibition of protein synthesis. Carbohydrates regulate the rate of $\mathrm{CO}_{2}$ fixation and /or synthesis or hydrolysis of starch both in the chloroplast (Gorai, 2010). In general, the carbohydrate content is used as a parameter to identify abiotic stress nature, such as water stress. According to (Lyse et al., 2012) under water stress of the willing carbohydrates in the cytoplasm, they are used in the activation of drought tolerance mechanisms, regardless of the mechanism in question. Usually in plants under stress, it is common to increase the accumulation of carbohydrates in the leaf and root. However, according to the results found in this study, with reduction of carbohydrate content in function of $\mathrm{N}$ doses (Marschner, 2012), nitrogen alters the composition of plants much more than any other nutrient and simultaneously to increase in nitrogen concentration is drastic reduction of the amount of reserved carbohydrates. The increase in carbohydrate content may also occur at seedlings without fertilization and fertilization with the highest dose was $30 \%$. Sucrose was recognized as the main sugar to act in maintaining cell turgor and regulating the osmotic adjustment (Farrant et al., 2009). Regarding the chlorophyll A content (Chla), only the application of ammonium nitrate provided significant effect to the adjustment of the regression model through regression analysis. There is the quadratic effect on levels of Chla depend on the $\mathrm{N}$ levels, resulting in the decrease of the curve near the higher fertilizer doses (Fig 8), which could be viewed from the unfolding of the interaction.

The use of $\mathrm{N}$ in chlorophyll production can be a plant's strategy to ensure adequate capture of light energy by photosystems (Carneiro et al., 2015). Leaves with a high nitrogen content have higher chlorophyll content, which results in improved photosynthetic capacity (Silva et al., 2011).

\section{Materials and methods}

\section{Site description and substrate preparation}

The experiment was conducted in a greenhouse of the Institute of Agricultural Sciences at the Federal Rural 
University of Amazonia in Belém, Pará, in the period from April to July 2015. The soil used as substrate was yellow latosol. It was characterized by analysis conducted by the Instituto Brasileiro de Análises (IBRA) (Table 1). After 30 days, the soil was fertilized with macronutrient via solution in the following doses: $\mathrm{P}=300 \mathrm{mg} \mathrm{dm}^{-3}, \mathrm{~K}=100 \mathrm{mg} \mathrm{dm}^{-3}$ and $\mathrm{S}=40 \mathrm{mg} / \mathrm{dm}^{3}$, having as sources $\mathrm{NaH}_{2} \mathrm{PO}_{4} \cdot \mathrm{H}_{2} \mathrm{O}, \mathrm{KCl}$ and $\mathrm{K}_{2} \mathrm{SO}_{4}$. And more, a micronutriente solution, in the following doses: $\mathrm{B}=0,81 \mathrm{mg} \mathrm{dm}^{-3}\left(\mathrm{H}_{3} \mathrm{BO}_{3}\right), \mathrm{Cu}=1,33 \mathrm{mg}$ $\mathrm{dm}^{-3} \quad\left(\mathrm{CuSO}_{4} \cdot 5 \mathrm{H}_{2} \mathrm{O}\right), \quad \mathrm{Mo}=0,15 \mathrm{mg} \mathrm{\textrm {dm } ^ { - 3 }}$ $\left[\left(\mathrm{NH}_{4}\right) 6 \mathrm{Mo}_{7} \mathrm{O}_{24} \cdot 4 \mathrm{H} 2 \mathrm{O}\right], \mathrm{Mn}=3,66 \mathrm{mg} \mathrm{dm}^{-3}\left(\mathrm{MnCl}_{2} \cdot \mathrm{H}_{2} \mathrm{O}\right) \mathrm{e}$ $\mathrm{Zn}=4,0 \mathrm{mg} \mathrm{dm}^{-3}\left(\mathrm{ZnSO}_{4} .7 \mathrm{H}_{2} \mathrm{O}\right)$ (Alvarez et al., 2006). After that, the substrate was placed in plastic pots with a capacity of $3 \mathrm{dm}^{3} /$ vessel.

\section{Plant materials}

The seeds of Tachi-branco (Tachigali vulgaris) were obtained from the seeds of forest sector of Embrapa Amazônia Oriental, harvested headquarters located in the municipality of Paragominas-PA ( $2^{\circ} 59$ '51 "S, $\left.47^{\circ} 21^{\prime} 13^{\prime \prime} \mathrm{W}\right)$ and germinated in seedbeds, with washed sand as substrate. After 30 days of the start of germination, 2 seedlings were transplanted per pot, with capacity of $3 \mathrm{dm}^{3}$ of soil. After another 30 days, one thinning was carried out, leaving only one plant per pot.

\section{Treatments and experimental design}

Nitrogen sources tested were urea $\left[\mathrm{CO}\left(\mathrm{NH}_{2}\right)_{2}\right]$ with $45 \%$ of $\mathrm{N}$; ammonium sulfate $\left[\left(\mathrm{NH}_{4}\right)_{2} \mathrm{SO}_{4}\right]$ with $21 \% \mathrm{~N}$ and $23 \%$ sulfur; ammonium nitrate $\left(\mathrm{NH}_{4} \mathrm{NO}_{3}\right)$ having $33.5 \% \mathrm{~N}$ (half from nitrate form and half from ammonium); and calcium nitrate $\left[\mathrm{Ca}\left(\mathrm{NO}_{3}\right)_{2}\right]$, having $15.5 \% \mathrm{~N}$ and $19 \%$ calcium. The fertilizers were applied in five doses of $0,75,150,225$ and $300 \mathrm{mg} \mathrm{dm}^{-3} \mathrm{~N}$ in the form of solution in four equal portions at 25, 50,75 and 100 days after transplanting to vessels.

The experimental unit consisted of a vase containing $3 \mathrm{dm}^{3}$ of soil, with a seedling. The experiment constitutes a randomized block design (RBD) in factorial scheme $(4 \times 5)$, corresponding to 4 sources of nitrogen and 5 doses, with four replications, totaling 80 vessels. The plant material to carry out the biochemical analysis was collected at the end of the experiment, 100 days after the start of treatment.

\section{Biochemical analyzes}

Biochemical analyzes were performed on Biodiversity Studies Laboratory in Higher Plants (EBPs), located at the Federal Rural University of Amazonia (UFRA), Belém, Pará. Therefore, we determined the levels of nitrate $\left(\mathrm{NO}_{3}{ }^{-}\right)$ (Cataldo et al., 1975); reductase enzyme activity of nitrate $\left(\mathrm{RNO}_{3}\right)$ (Hageman; Hucklesby, 1971); free ammonium $\left(\mathrm{NH}_{4}^{+}\right)$(Weatherburn, 1967); soluble amino acids (TSAA) (Peoples et al., 1989); total soluble protein (PST) (Bradford, 1976); carbohydrates (Dubois et al., 1956); sucrose (Van Handel, 1968) and; chlorophylls (Lichthenthaler, 1987).

\section{Statistical analysis}

Analysis of variance was performed depend on the significance of the F-test for the interaction between factors Sources $\times$ nitrogen. Developments were conducted to evaluate the effect of doses (quantitative) within each nitrogen source (qualitative) for through polynomial regression of first and second degrees. In cases where the interaction nitrogen sources $\times$ nitrogen levels was not significant $(p>0.05)$ the factors were analyzed separately. The effects due to nitrogen sources were compared by Tukey's test. The effect of nitrogen doses was assessed through polynomial regression of first and second degrees. The 5\% significance level was applied for all statistical tests. For regression equations, the significance of the coefficients and the coefficient of determination $\left(R^{2}\right)$ were also calculated.

\section{Conclusion}

With application of ammonium nitrate and calcium nitrate, there was a reduction in the concentration of protein in leaf and root, which may be related to the formation of reactive oxygen species (ROS) by excess $\mathrm{NO}_{3}^{-}$, causing damage to photosystems and inhibition of protein synthesis. The accumulation of amino acids in the leaf and root was positively influenced by the application of $\mathrm{N}$, occurring maximum accumulation with the source of nitrate ammonium in doses upcoming of $225 \mathrm{mg} \mathrm{dm}^{-3}$. The increase of amino acid content in the leaf and root can be the plant's strategy to cope with detoxification of ROS. The conversion of nitrate into amino acids in root depends on the oxidation of carbohydrates, causing the reduction of the concentration of this solute with the $\mathrm{NO}_{3}{ }^{-}$supply. Based on the results, for the production of Tachigali vulgaris seedlings the dose of 150 $\mathrm{mg} \mathrm{dm} \mathrm{d}^{-3}$ of $\mathrm{N}$, applied in a piecemeal manner, at $25,50,75$ and 100 days with the ammonium nitrate fertilizer is recommended.

\section{Acknowledgements}

The authors are grateful to the Universidade Federal Rural da Amazônia for the financial support of this work and collaborations of researchers participating in the Biodiversity Study Group in Higher Plants.

\section{References}

Beltrão NDM, Oliveira MIP (2007) Biossíntese e degradação de Lipídios, Carboidratos e Proteínas em oleaginosas. In: Embrapa Documentos, Campina Grande, Paraíba. 62p.

Borgognone D, Colla G, Rouphael Y, Cardarelli M, Rea E, Schwarz D (2013) Effect of nitrogen form and nutrient solution $\mathrm{pH}$ on growth and mineral composition of selfgrafted and grafted tomatoes. Sci Hortic. 149(1):61-69.

Bradford MM (1976) A rapid and sensitive method for the quantitation of microgram quantities of protein utilizing the principle of protein-dye binding. Anal Biochem. 72(12):248-254.

Bredemeier C, Mundstock CM (2000) Regulação da absorção e assimilação do nitrogênio nas plantas. Cienc Rural. 30(2):365-372.

Carneiro MM, Gomes MP, Santos HR, dos Reis MV, Mendonça AMDC, de Oliveira LE (2015) Fotorrespiração e metabolismo antioxidante em plantas jovens de seringueira cultivadas sob diferentes fontes de nitrogênio. Rev Bras Cienc Agrarias. 10(1):66-73.

Carpanezzi AA, Marques LCT, Kanashiro M. Aspectos ecológicos e silviculturais de taxi-branco-da-terra-firme (Sclerolobium paniculatum Vogel). EMBRAPAURPFCS, 1983.

Cataldo DA, Maroon M, Schrader LE, Youngs VL (1975) Rapid colorimetric determination of nitrate in plant tissue by nitration of salicylic acid. Soil Sci Plant Anal. 6(1):7180 . 
Davies CS (2000) Strategy differences of two potato species in response to nitrogen starvation. Do plants have a genetic switch for nitrogen signalling? Plant, Cell and Environ. 23:759-769.

Dubois M, Gilles KA, Hamilton JK, Rebers P, Smith F (1956) Colorimetric method for determination of sugars and related substances. Anal Chem. 28(3):350-356.

Ducke A (1949) Notas sobre a flora neotrópica II: As leguminosas da Amazônia Brasileira. Boletim Técnico do Instituto Agronômico do Norte, Belém, 248p.

Farrant JM, Lehner A, Cooper K, Wiswedel S. (2009) Desiccation tolerance in the vegetative tissues of the fern Mohria caffrorum is seasonally regulated. Plant J. 57(1):65-79.

Gorai M, Maraghni M, Neffati M (2010) Relationship between phenological traits and water potential patterns of the wild jujube Ziziphus lotus (L.) Lam. in southern Tunisia. Plant Ecol Divers. 3(3):273-280.

Hageman RH, Hucklesby DP (1971) Nitrate reductase from higher plants. Methods Enzymol. 17:491-503.

Jampeetong A, Brix H, Kantawanichkul S (2012) Response of Salvinia cucullata to high $\mathrm{NH}_{4}{ }^{+}$concentrations at laboratory scales. Ecotox Environ Saf. 79:69-74.

Lasa B, Frechilla S, Aleu M, González-Moro B, Lamsfus C, Aparicio-Tejo PM (2000) Effects of low and high levels of magnesium on the response of sunflower plants grown with ammonium and nitrate. Plant Soil. 225:167-174.

Lichtenthaler HK (1987) Chlorophyll and carotenoids: pigments of photosynthetic biomembranes. Methods Enzymol. 148:362-385.

Lopes AS, Bastos ARR, Daher E (2007) Uso eficiente dos fertilizantes nitrogenadas e sulfatados na agricultura brasileira: Uma visão do futuro. In: Yamada T, Abdalla SRS, Vitti GC (Ed). Nitrogênio e enxofre na agricultura brasileira. Piracicaba: IPNI Brasil, 5, 187p.

Marschner H (2012) Marschner's mineral nutrition of higher plants. In: 3rd. ed. London:

Academic Press. 651p.

Neuberg M, Pavlíková D, Pavlík M, Balík J (2010) The effect of different nitrogen nutrition on proline and asparagine content in plant. Plant Soil Environ. 56(7):305-311.

Oliveira LAA, Barreto LP, Bezerra Neto E, Santos MVFD, Costa JDCA (2006) Solutos orgânicos em genótipos de sorgo forrageiro sob estresse salino. Pesq Agropeca Brasileira. 41(1):31-35.

Peoples MB, Faizah AW, Rerkasem B, Herridge DF (1989) Methods for evaluating nitrogen fixation by nodulated legumes in the field. Australian Centre for International Agricultural Research, Canberra. 76p.
Ribeiro GT, Paiva HN, Jacovine LAG, Trindade C (2001) Produção de mudas de Eucalipto. In: Viçosa: Aprenda Fácil, 112p.

Silva SM, Oliveira LJ, Faria FP, dos Reis EF, Carneiro MAC, da Silva SM (2011). Atividade da enzima nitrato redutase em milho cultivado sob diferentes níveis de adubação nitrogenada e potássica. Cienc Rural. 41(11):1931-1937.

Silva LFG, Lima HC (2007) Mudanças nomenclaturais no gênero Tachigali Aubl. (Leguminosae-Caesalpinioideae) no Brasil. Rodriguésia, 401p.

Scheer MB, Carneiro C, Santos KG (2010) Substratos à base de lodo de esgoto compostado na produção de mudas de Parapiptadenia rigida (Benth.) Brenan. Scient Forest. 38(88):637-644.

Schröder JJ, Neeteson JJ, Oenema O, Struik PC (2000) Does the crop or the soil indicate how to save nitrogen in maize production? Reviewing the state of art. Field Crops Res. 66(2):151-164.

Sinfield JV, Fagerman D, Colic O (2010) Evaluation of sensing technologies for on-the-go detection of macronutrients in cultivated soils. Comp and Electron in Agric. 70(1):1-18.

Tucci CAF, Lima HN, Lessa JF (2009) Adubação nitrogenada na produção de mudas de mogno (Swietenia macrophylla King). Acta Amaz 39(2):289-294.

Vale AT, Brasil MAM, Leão AL (2002) Quantificação e caracterização energética da madeira e casca de espécies do cerrado. Cienc Florest. 12(1):71-80.

Van Handel E (1968) Direct microdetermination of sucrose. Anal Biochem 22(2):280-283.

Weatherburn MW (1967) Phenol-hypochlorite reaction for determination of ammonia. Anal Chem. 39:971-974.

Yared JAG (1990) Silvicultura de algumas espécies nativas da Amazônia. In: Congresso Florestal Brasileiro, Campos do Jordão, São Paulo. 6:19-122.

Zhu Z, Gerendás J, Bendixen R, Schinner K, Tabrizi H, Sattelmacher B, Hansen UP (2000) Different tolerance to light stress in $\mathrm{NO}_{3}{ }^{-}$and $\mathrm{NH}_{4}{ }^{+}$grown Phaseolus vulgaris $\mathrm{L}$. Plant biol. 2(5):558-570. 